\title{
Pengaruh Pemahaman Akuntansi dan Pemahaman Perpajakan terhadap Kepatuhan Wajib Pajak pada KPP Pratama Madiun
}

\author{
Huda Trihatmoko ${ }^{1}$ \\ Fakultas Ekonomi dan Bisnis \\ Universitas Airlangga, Indonesia
}

\author{
Muhammad Raihan Mubaraq ${ }^{2}$ \\ Fakultas Ekonomi dan Bisnis \\ Universitas Airlangga, Indonesia
}

\begin{abstract}
Surel : hudatrihatmoko@yahoo.com
ABSTRAK

Penelitian bertujuan untuk memberikan bukti empiris pengaruh pemahaman akuntansi dan pemahaman perpajakan terhadap kepatuhan wajib pajak. Pengukuran variabel dalam penelitian ini menggunakan skala likert dari skala 1 untuk sangat tidak setuju sampai dengan skala 4 untuk sangat setuju. Sampel dalam penelitian ini adalah 112 wajib pajak orang pribadi di KPP Pratama Madiun. Pengambilan sampel mengacu rumus Slovin dengan metode purposive sampling dan dianalisis menggunakan regresi linier berganda. Hasil penelitian ini menunjukkan bahwa pemahaman akuntansi tidak berpengaruh terhadap kepatuhan wajib pajak, sedangkan pemahaman perpajakan berpengaruh terhadap kepatuhan wajib pajak.
\end{abstract}

Kata Kunci: Pemahaman Akuntansi; Pemahaman Perpajakan; Kepatuhan Wajib Pajak.

\section{The Effect Understanding of Accounting and Understanding of Taxation on Taxpayer Compliance in KPP Pratama Madiun}

\section{ABSTRACT}

The research aims to provide empirical evidence of the influence understanding of accounting and understanding of taxation on taxpayer compliance. Measurement of variables in this study using a Likert scale from scale 1 to strongly disagree to scale 4 to strongly agree. The sample in this study was 112 individual taxpayers in KPP Pratama Madiun. Sampling refers to the Slovin formula with a purposive sampling method and analyzed using multiple linear regression. The results of this study indicate that the understanding of accounting has no effect on taxpayer compliance while understanding of taxation has an effect on taxpayer compliance.

Keywords: Understanding of Accounting; Understanding of Taxation; Taxpayer Compliance.

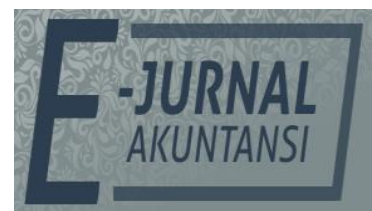

e-ISSN 2302-8556

Vol. 30 No. 9

Denpasar, September 2020

Hal. 2231-2243

DOI:

10.24843/EJA.2020.v30.i09.p05

PENGUTIPAN:

Trihatmoko, H. \& Mubaraq, M. R. (2020). Pengaruh

Pemahaman Akuntansi dan

Pemahaman Perpajakan terhadap Kepatuhan Wajib

Pajak pada KPP Pratama

Madiun. E-Jurnal Akuntansi, 30(9), 2231-2243

RIWAYAT ARTIKEL:

Artikel Masuk: 18 Juni 2020 Artikel Diterima: 24 Agustus 2020

Artikel dapat diakses : https://ojs.unud.ac.id/index.php/Akuntansi/index 


\section{PENDAHULUAN}

Pajak merupakan tulang punggung penerimaan bagi negara yang memiliki peran penting dalam berbagai sektor utamanya dalam hal pembangunan dan sumber pembiayaan negara. Kepatuhan merupakan elemen yang mampu mempengaruhi target negara dalam hal realisasi penerimaan pajak. Semakin wajib pajak patuh, maka penerimaan negara juga akan semakin meningkat. Menurut Rohmawati \& Rasmini (2012), hal ini dapat tercermin dalam kepatuhan mendaftar, menyetor, menghitung, membayar pajak terutang dan tunggakan jika ada. Seseorang dapat dikatakan patuh apabila terdaftar dan melaporkan kewajiban perpajakannya.

Mengutip dari Ekonomi \& Bisnis, Senin (15/7/2019) Direktorat Jenderal Pajak Kementerian Keuangan berupaya untuk memaksimalkan wajib pajak potensial yang selama ini belum memiliki kesadaran untuk membayar pajak. Pemerintah menilai jumlah wajib pajak yang terdata saat ini masih jauh dari jumlah potensial. Sejauh ini jumlah wajib pajak yang terdata untuk wajib pajak orang pribadi mencapai 42,5 juta dan wajib pajak badan 3,5 juta. Angka ini dinilai sangat kecil dengan jumlah pekerja yang ada di Indonesia yang mencapai sekitar 115 juta. Direktur Jenderal Pajak (DJP) menegaskan bahwa tingkat kepatuhan hingga Juli 2019 baru mencapai 12,3 juta atau sekitar 67,2 persen dari jumlah wajib pajak sejumlah 18,3 juta. Data orititas pajak menunjukkan bahwa kelompok yang paling patuh adalah wajib pajak karyawaran dengan rasio kepatuhan 73,6 persen, diikuti kelompok korporasi dengan rasio kepatuhan 57,28 persen dan yang terakhir wajib pajak orang kaya atau nonkaryawan dengan rasio kepatuhan dibawah 50 persen atau 42,75 persen (Suwiknyo, 2019). Ini mengindikasikan bahwa tingkat kepatuhan pajak di Indonesia masih sangat rendah, hal ini dapat dilihat dengan masih banyaknya masyarakat umum yang memiliki kewajiban membayar pajak tetapi belum mendaftarkan dirinya ke kantor pajak.

Pencapaian penerimaan pajak pada KPP Pratama Serang Barat masih rendah sehingga kepatuhan pajak dinilai jauh dari yang diharapkan. Mengutip Kabar Banten, Minggu (1/3/2020) tercatat sepanjang tahun 2019, hanya 60 persen saja pajak yang dibayarkan oleh wajib pajak. Pencapaian tersebut jauh dari target yang ditetapkan diawal oleh KPP Pratama Serang Barat yaitu minimal 73 persen. Kepala KPP Serang Barat, Triyani Yuningsih mengatakan bahwa pihaknya menargetkan pajak sebesar 1,18 triliun rupiah, tetapi pada kenyataannya hanya 60 persen atau sekitar 708 miliar rupiah saja yang berhasil dibayarkan wajib pajak. Dari jumlah tersebut sebagian besar bersumber dari administrasi pemerintah sekitar 34 persen (Putri, 2020).

Hal serupa juga dialami oleh KPP Pratama Madiun. Mengutip dari GE FM Madiun, Kamis (21/3/2019) ribuan wajib pajak di wilayah madiun belum melaporkan SPT tahunan pajak penghasilan. Dari data yang ada, tercatat target 44.146 wajib pajak, baru tercapai sekitar 36.617, artinya masih kurang 7.529 untuk mencapai target yang sudah ditetapkan. Dari jumlah itu wajib pajak pribadi sekitar 35.324 dan wajib pajak badan hukum sekitar 1.293 (Ika, 2019).

Kepatuhan pelaporan SPT tahunan di KPP Pratama Madiun juga dinilai masih rendah. Mengutip dari Radar Madiun, Senin (21/1/2020) KPP Pratama Madiun menargetkan peningkatan pelaporan SPT dibandingkan tahun 
sebelumnya. Hal ini dikarenakan target penerimaan pajak di Direktorat Jenderal Pajak (DJP) Kantor Wilayah I Jatim naik 23 persen dibandingkan tahun sebelumnya. Pada tahun 2019 target penerimaan pajak sebesar 49,97 triliun rupiah, sedangkan untuk tahun 2020 menjadi 54,703 triliun rupiah. Kenaikan ini tentunya berimbas pada target penerimaan pajak KPP Pratama Madiun (Fitri, 2020).

Salah satu faktor yang penting dalam keberhasilan untuk meningkatkan kesadaran akan kepatuhan wajib pajak dalam melaporkan dan membayar kewajiban perpajakannya adalah dengan sistem self assessment. Menurut Palil \& Mustapha (2011) self assessment dapat mempengaruhi kepatuhan wajib pajak. Indonesia menganut sistem self assessment dalam sistem perpajakannya, yaitu memberikan kebebasan dan kepercayaan seutuhnya kepada wajib pajak dari mulai menghitung sampai melaporkan sesuai dengan peraturan perpajakan yang berlaku (Rusli, Zirman, \& Puspitasari, 2015). Diharapkan dengan self assessment wajib pajak bisa melaporkan tanggungan pajaknya dengan sebaikbaiknya.

Wajib pajak diberikan kebebasan untuk melaporkan kewajiban perpajakannya mulai dari menghitung sampai dengan melaporkan secara mandiri. Hal ini tentunya akan berjalan optimal apabila wajib pajak memiliki pemahaman yang baik bagaimana menghitung sampai dengan melaporkan kewajiban perpajakannya. Pemahaman yang diperlukan untuk mendukung hal ini adalah berkaitan dengan pemahaman yang dimiliki wajib pajak mengenai akuntansi yakni apakah dalam memperoleh penghasilan wajib pajak melakukan pencatatan dan pembukuan. Menurut Rusli, Hardi, \& Pakpahan (2015), apabila wajib pajak dapat paham dan melaksanakan akuntansi sesuai dengan peraturan yang berlaku maka akan memudahkan wajib pajak itu sendiri untuk menghitung dan secara tidak langsung ikut meningkatkan kepatuhan wajib pajak. Hal ini sejalan dengan apa yang dikatakan Dartini \& Jati (2016) yang mengatakan bahwa pemahaman akuntansi memiliki pegaruh terhadap kepatuhan wajib pajak.

Pemahaman akuntansi yang baik erat hubungannya dengan pemahaman akan perpajakan. Pemahaman perpajakan ini berhubungan dengan berapa kewajiban yang harus dibayar, tarif yang diberlakukan dan bagaimana melaporkannya. Menurut Rusli, Zirman, et al. (2015) apabila peraturan perpajakan dapat dipahami dengan baik oleh wajib pajak maka kemungkinan wajib pajak tersebut untuk membayar kewajibannya juga baik, sehingga semakin wajib pajak paham peraturan pajak maka kepatuhan juga akan meningkat. Hal serupa juga dikatakan Ananda, Kumadji, \& Husaini (2015) bahwa penting bagi seluruh wajib pajak untuk memiiki pemahaman perpajakan yang baik untuk meningkatkan kesadaran dan kepatuhan membayar pajak. Hal ini diperkuat dengan penelitian yang dilakukan Sumianto \& Kurniawan (2015), Kartika \& Aji (2015) yang menyatakan bahwa pemahaman perpajakan memiliki pengaruh terhadap kepatuhan wajib pajak.

Peraturan perpajakan yang berlaku sangat erat hubungannya dengan perpajakan dan akuntansi yang dalam hal ini memudahkan wajib pajak untuk dapat mengetahui peraturan dan cara melaporkan yang benar. Peraturan perpajakan di Indonesia tidak mewajibkan semua wajib pajak untuk melakukan pembukuan atau pencatatan. Pembukuan hanya diwajibkan kepada wajib pajak 
yang memiliki penghasilan lebih dari 4,8 miliar per tahun, sedangkan yang wajib pajak yang memiliki penghasilan kurang dari 4,8 miliar per tahun diperkenankan hanya melakukan pencatatan. Namun, untuk wajib pajak badan wajib melakukan pembukuan tanpa melihat jumlah penghasilan yang diperoleh. Diberlakukan peraturan seperti ini bertujuan untuk tidak memberatkan wajib pajak untuk menghitung dan membayar pajaknya. Dalam melakukan perhitungan wajib pajak harus tunduk kepada Standar Akuntansi Keuangan (SAK) agar ada keselarasan dan mudah dipahami oleh semua pihak (Ikatan Akuntan Indonesia, 2013).

Salah satu yang terkena wajib pajak adalah UKM. Kepatuhan pajak UKM dipengaruhi oleh pemahaman tentang akuntansi pajak dan pemahaman pajak. Mayoritas UKM memiliki kekurangan dalam pemahaman tentang akuntansi pajak dan sebagian besar tidak paham akan peraturan pajak (Setyorini, 2018). UKM di negara berkembang banyak yang tidak mematuhi undang-undang perpajakan. Mereka hanya memiliki pengetahuan dasar tentang pajak dan tidak memiliki pemahaman yang lebih mendalam tentang masalah pajak (Newman, Mwandambira, Charity, \& Ongayi, 2018). Menurut Djatmiko (2018) hal ini dapat diatasi dengan pemahaman wajib pajak yang semakin baik sehingga semakin baik pula kepatuhannya. Jika wajib pajak memahami perpajakan lebih baik, kepatuhan mereka untuk melaksanakan kewajiban akan meningkat. Adanya pengaruh ini menunjukkan bahwa pemahaman yang lebih baik dari wajib pajak akan mempengaruhi peningkatan kepatuhan wajib pajak.

Banyak wajib pajak yang memiliki pengetahuan teknis yang tidak memadai dan menganggap sistem pajak sebagai sesuatu yang kompleks. Pengetahuan pajak dan kompleksitas pajak sering dianggap sebagai komponen yang berperan andil terhadap perilaku ketidakpatuhan di antara wajib pajak (Saad, 2014). Menurut Rizal Palil \& Rusyidin Md Akir (2013) bahwa kepatuhan pajak lebih rendah dibandingkan dengan pendidikan dan pengetahuan wajib pajak terhadap pajak itu sendiri. Pengetahuan itu sendiri lebih lanjut menurut Pratama (2018) sangat bergantung kepada usia dan tingkat pendapatan.

Banyak penelitian yang mengatakan bahwa pemahaman akan perpajakan sangat penting dalam mencapai target penerimaan pajak. Hasil penelitian Kurniawan (2020), Panjaitan, Tarmizi, Daulay, \& Ginting (2019), Oktaviani, Juang, \& Kusumaningtyas (2017) dan Oladipupo \& Obazee (2016) menunjukkan bahwa pengetahuan pajak memiliki pengaruh positif signifikan terhadap kepatuhan. Dengan demikian, pengetahuan pajak memiliki kecenderungan yang lebih tinggi untuk mempromosikan kepatuhan pajak. Karena itu pemerintah harus melakukan segala yang mungkin untuk meningkatkan pengetahuan publik tentang masalah pajak dan kesadaran pajak mereka untuk saling menguntungkan pemerintah dan pembayar pajak. Hal yang berbeda di sampaikan oleh Kamil (2015) yang mengatakan bahwa pengetahuan memiliki hubungan negatif dan signifikan kepatuhan wajib pajak. Ini menandakan bahwa sebenarnya wajib pajak memiliki tingkat pengetahuan tentang pajak yang baik akan berusaha mencari celah agar terhindar dari kewajiban membayar pajak.

Pemahaman akuntansi yang baik akan memudahkan wajib pajak dalam melakukan kewajibannya. Pemahaman akuntansi berkaitan dengan kemampuan untuk mengerti serta memahami proses transaksi hingga menjadi laporan 
keuangan. Wajib pajak bisa dikatakan memiliki pemahaman yang baik apabila dapat dengan tepat melakukan pembukuan. Wajib pajak yang memahami hal ini dengan bagus maka niat untuk patuh juga meningkat. Menurut Rusli, Hardi, et al. (2015), pemahaman akuntansi memiliki pengaruh terhadap kepatuhan wajib pajak berkaitan tanggungan yang harus dibayarkan. Kepatuhan wajib pajak ini tentunya hasil dari pemahaman wajib pajak mengenai akuntansi yang baik sehingga hasilnya benar dan tepat serta meningkatkan minat wajib pajak tersebut untuk patuh membayar hingga melaporkan kewajibannya.

$\mathrm{H}_{1}$ : Pemahaman akuntansi berpengaruh positif terhadap kepatuhan wajib pajak.

Pemahaman perpajakan merupakan hal yang dapat membantu proses perpajakan menjadi lebih akurat. Pemahaman perpajakan berkaitan dengan pengetahuan wajib pajak mengenai peraturan yang diberlakukan. Wajib pajak bisa dibilang memiliki pemahaman yang baik jika dapat menghitung, membayar, mengisi, melaporkan sendiri dengan tepat waktu dengan tetap memahami sanksi yang akan dikenakan apabila ada keterlambatan dalam pembayaran atau pelaporan pajak. Menurut Rusli, Zirman, et al. (2015), pemahaman perpajakan memiliki pengaruh terhadap kepatuhan wajib pajak. Hal ini berarti semakin bagus pemahaman yang dimiliki seorang wajib pajak maka kepatuhannya juga akan ikut meningkat. Pemahaman ini berkaitan dengan kemampuan mengenai peraturan perpajakan yang berlaku saat ini di Indonesia. Kemudahan dan kesederhanaan ini diharapkan mampu membantu dan mempermudah setiap wajib pajak untuk sadar menunaikan kewajibannya.

$\mathrm{H}_{2}$ : Pemahaman perpajakan berpengaruh positif terhadap kepatuhan wajib pajak

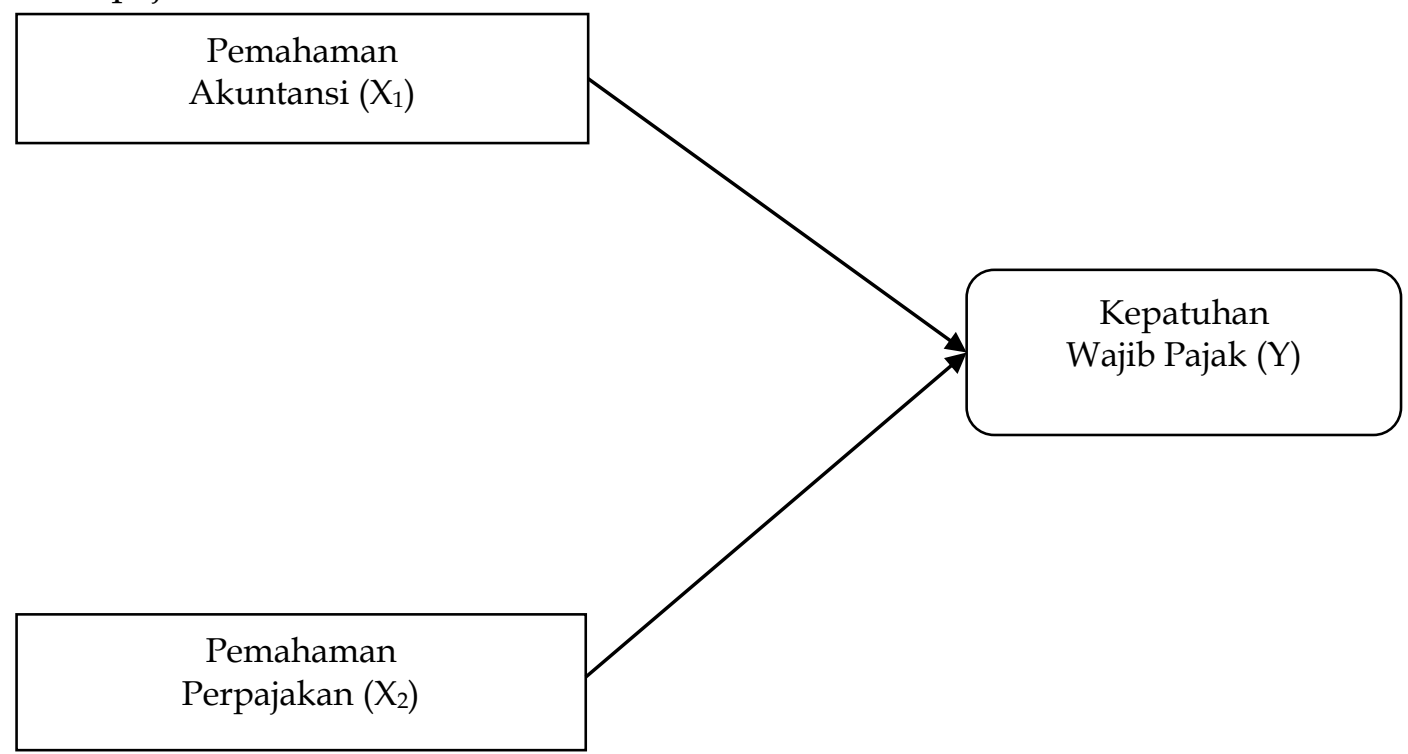

Gambar 1. Model Penelitian

Sumber: Data Penelitian, 2020

\section{METODE PENELITIAN}

Sampel dalam penelitian ini adalah wajib pajak orang pribadi yang aktif melaporkan pajaknya dan terdaftar di KPP Pratama Madiun. Jumlah wajib pajak yang aktif dan terdaftar di KPP Pratama Madiun sebanyak 44.146 wajib pajak. 
Pemilihan besaran sampel yang dapat digunakan mengacu rumus Slovin sebagai berikut (Umar, 2008).

$$
\begin{aligned}
\mathrm{n}=\frac{\mathrm{N}}{1+\mathrm{Ne}^{2}} & =\frac{44.146}{1+\left(44.146 \times(0,1)^{2}\right.} \\
& =99,77
\end{aligned}
$$

Keterangan :

$\mathrm{n} \quad=$ Jumlah sampel

$\mathrm{N} \quad=$ Jumlah populasi

e $\quad=$ Prosentase ketidaktelitian (batas toleransi) $10 \%$

Dari perhitungan sampel menggunakan rumus Slovin diatas didapatkan jumlah sampel yang digunakan yaitu 100 responden dengan teknik pengambilan purposive sampling.

Pemahaman akuntansi dalam penelitian ini diukur berdasarkan indikator mencatat dan pengelompokkan transaksi, membuat jurnal, pencatatan, proses penggolongan dan pengikhtisaran, pembuatan neraca saldo dan laporan keuangan, pembuatan laporan laba rugi serta mengalisis hasil laporan keuangan. Pengukuran variabel menggunakan skala likert dari skor 1 untuk kategori sangat tidak setuju, skor 2 untuk kategori tidak setuju, skor 3 untuk kategori setuju dan skor 4 untuk kategori sangat setuju.

Pemahaman perpajakan dalam penelitian ini diukur berdasarkan indikator reformasi serta sistem peraturan pajak, sarana identitas dan administrasi NPWP, batas akhir pelaporan, sanksi yang diberlakukan, denda yang harus ditanggung, menghitung dan membayar pajak serta penerimaan tanda bukti pelaporan SPT. Variabel diukur dengan menggunakan skala likert dari skor 1 untuk kategori sangat tidak setuju, skor 2 untuk kategori tidak setuju, skor 3 untuk kategori setuju dan skor 4 untuk kategori sangat setuju.

Kepatuhan wajib pajak dalam penelitian ini diukur berdasarkan indikator pendaftaran diri, pelaporan dan isian SPT Masa dan Tahunan, penghitungan jumlah pajak yang harus dibayar, ketepatan waktu dalam menyetor pajak, ketepatan waktu dalam melaporkan pajak, serta pembayaran tunggakan pajak. Pengukuran variabel menggunakan skala likert dari skor 1 untuk kategori sangat tidak setuju, skor 2 untuk kategori tidak setuju, skor 3 untuk kategori setuju dan skor 4 untuk kategori sangat setuju.

Hubungan antar variabel dapat diuji menggunakan teknik analisis regresi linier berganda dengan menggunakan persamaan sebagai berikut.

$$
\mathrm{Y}=\alpha+\beta_{1} \mathrm{PA}+\beta_{2} \mathrm{PP}+\varepsilon
$$

Keterangan :

$$
\begin{array}{ll}
\mathrm{Y} & =\text { Kepatuhan wajib pajak } \\
\alpha & =\text { Konstanta } \\
\beta_{1}, \beta_{2} & =\text { Koefisien variabel } \\
\mathrm{PA} & =\text { Pemahaman Akuntansi } \\
\mathrm{PP} & =\text { Pemahaman Perpajakan } \\
\varepsilon & =\text { Error }
\end{array}
$$




\section{HASIL DAN PEMBAHASAN}

Analisis deskriptif digunakan untuk melihat gambaran secara umum mengenai persebaran data yang dalam penelitian ditampilkan jumlah responden, jumlah pernyataan, rata-rata minimum, rata-rata maksimum dan juga rata-rata secara keseluruhan. Hasil uji statistik deskriptif dapat dilihat pada Tabel 1.

\section{Tabel 1. Hasil Uji Statistik Deskriptif}

\begin{tabular}{lccccc}
\hline \multicolumn{1}{c}{ Variabel } & $\mathrm{N}$ & Statements & $\begin{array}{c}\text { Mean } \\
\text { Minimum }\end{array}$ & $\begin{array}{c}\text { Mean } \\
\text { Maximum }\end{array}$ & $\begin{array}{c}\text { Mean } \\
\text { All }\end{array}$ \\
\hline Kepatuhan Wajib Pajak & 112 & 6 & 3,08 & 3,14 & 3,11 \\
Pemahaman Akuntansi & 112 & 8 & 2,97 & 3,10 & 3,04 \\
Pemahaman Perpajakan & 112 & 5 & 2,96 & 3,15 & 3,05 \\
\hline
\end{tabular}

Sumber: Data Penelitian, 2020

Variabel kepatuhan wajib pajak memperoleh nilai rata-rata keseluruhan yakni 3,11. Hal ini menunjukkan bahwa responden menjawab pilihan setuju untuk rata-rata secara keseluruhan. Artinya para wajib pajak tahu bahwa kepatuhan seorang wajib pajak dalam melakukan kewajiban perpajakan itu perlu sebagai bentuk sumbangsih warga negara terhadap negara demi kemajuan negara. Variabel kepatuhan wajib pajak mempunyai enam pernyataan. Berdasarkan enam pernyataan tersebut terdapat nilai rata-rata yang tertinggi dan terendah dari jawaban para responden. Pernyataan nomer satu adalah pernyataan yang mempunyai nilai tertinggi secara rata-rata yang berisi bahwa responden sepakat wajib pajak dikatakan patuh jika mendaftarkan atas keinginan sendiri atas dasar kesadaran dan kemauan sendiri tanpa ada tekanan dan paksanaan dari manapun. Pernyataan yang mempunyai nilai terendah secara rata-rata adalah penyataan nomer empat yang berisi bahwa ada atau tidaknya pemeriksaan pajak tidak serta merta membuat wajib pajak membayar pajak secara tepat waktu.

Variabel pemahaman akuntansi memperoleh nilai rata-rata keseluruhan yakni 3,04. Hal ini menunjukkan bahwa responden menjawab pilihan setuju untuk rata-rata secara keseluruhan. Artinya, bahwa seorang wajib pajak memahami akuntansi untuk mempermudah wajib pajak dalam mengetahui berapa besar pemasukan dan pengeluaran yang terjadi, selain itu juga mempermudah wajib pajak dalam menghitung dan menentukan pajak yang harus dibayar. Variabel pemahaman akuntansi mempunyai delapan pernyataan. Berdasarkan delapan pernyataan tersebut terdapat nilai rata-rata tertinggi dan terendah dari jawaban para responden. Pernyataan nomer satu adalah pernyataan yang mempunyai nilai tertinggi secara rata-rata yang berisi bahwa responden setuju wajib pajak melakukan pencatatan setiap kali ada transaksi. Wajib pajak yang dapat melakukan pencatatan transaksi yang terjadi secara rutin ini lebih dapat mempermudah wajib pajak untuk tahu berapa pemasukan dan pengeluaran yang terjadi pada saat itu. Pernyataan yang mempunyai nilai terendah secara rata-rata adalah penyataan nomer dua yang berisi bahwa setelah mencatat transaksi, wajib pajak tidak mengelompokkannya transaksi kedalam kelompok akunnya. Wajib pajak berpendapat bahwa melakukan pencatatan transaksi saja sudah cukup dan tidak perlu mempersulit diri.

Variabel pemahaman perpajakan memperoleh nilai rata-rata keseluruhan yakni 3,05. Hal ini menunjukkan bahwa responden menjawab pilihan setuju 
untuk rata-rata secara keseluruhan. Artinya, wajib pajak memahami akan perpajakan dari proses mendaftarkan, melakukan pembayaran pajak sampai pelaporan surat pemberitahuan serta berbagai macam peraturannya. Variabel pemahaman perpajakan mempunyai lima pernyataan. Berdasarkan lima pernyataan tersebut terdapat nilai rata-rata tertinggi dan terendah dari jawaban para responden. Pernyataan nomer satu adalah pernyataan yang mempunyai nilai tertinggi secara rata-rata yang berisi bahwa responden mengerti kewajiban perpajakan jika usia tujuh belas tahun dan sudah berpenghasilan dan diwajibkan memiliki NPWP sebagai identitas wajib pajak. Pernyataan yang memiliki nilai terendah secara rata-rata adalah penyataan nomer tiga yang berisi bahwa kurang mengerti mengenai pengenaan denda jika melaporkan SPT melewati batas yang telah ditentukan.

Pengujian validitas dilakukan dengan melihat nilai Pearson Correlation. Item kuesioner dalam penelitian ini sejumlah 19 pernyataan. Hasil uji validitas dapat dilihat pada Tabel 2.

Tabel 2. Hasil Uji Validitas

\begin{tabular}{lccc}
\hline \multicolumn{1}{c}{ Variabel } & Rhitung & Sig. & Keterangan \\
\hline Kepatuhan Wajib Pajak & $0,819-0,899$ & 0,00 & Valid \\
Pemahaman Akuntansi & $0,698-0,907$ & 0,00 & Valid \\
Pemahaman Perpajakan & $0,657-0,852$ & 0,00 & Valid
\end{tabular}

Sumber: Data Penelitian, 2020

Hasil uji validitas menunjukkan bahwa instrumen penelitian yang terdiri dari item-item pernyataan kepatuhan wajib pajak, pemahaman akuntansi dan pemahaman perpajakan adalah valid. Hal ini dikarenakan tingkat signifikansi dari ketiga variabel tersebut kurang dari 0,05 .

Uji reliabilitas menggunakan Cronbach's Alpha dengan kriteria pengambilan sebagaimana dinyatakan oleh Ghozali (2016), yaitu jika koefisien Cronbach's Alpha>0,6 maka instrumen dikatakan reliabel, sebaliknya jika nilai Cronbach's Alpha<0,6 maka instrumen dikatakan tidak reliabel. Hasil uji reliabilitas dapat dilihat pada Tabel 3.

\section{Tabel 3. Hasil Uji Reliabilitas}

\begin{tabular}{ccc}
\hline Variabel & Cronbach's Alpha & Keterangan \\
& & \\
\hline Kepatuhan Wajib Pajak & 0,806 & Reliabel \\
Pemahaman Akuntansi & 0,794 & Reliabel \\
Pemahaman Perpajakan & 0,803 & Reliabel
\end{tabular}

\section{Sumber: Data Penelitian, 2020}

Hasil uji reliabilitas menunjukkan bahwa nilai koefisien Cronbach's Alpha dari semua variabel lebih dari 0,60 sehingga dapat dikatakan bahwa semua variabel tersebut reliabel dan layak digunakan sebagai alat ukur instrumen kuesioner dalam penelitian ini.

Analisis regresi linier berganda digunakan untuk melihat pengaruh variabel independen terhadap variabel dependen. Hasil regresi linier berganda dapat dilihat pada Tabel 4 . 
Tabel 4. Hasil Regresi Linier Berganda

\begin{tabular}{lccccc}
\hline Model & \multicolumn{2}{l}{ Unstandardized Coefficients } & Standardized Coefficients & $\mathrm{t}$ & \multirow{2}{*}{ Sig. } \\
\cline { 2 - 4 } & $\mathrm{B}$ & Std. Error & Beta & & \\
\hline (Constant) & 8,594 & 1,524 & & 5,639 & 0,000 \\
PA $\left(\mathrm{X}_{1}\right)$ & $-0,123$ & 0,078 & $-0,162$ & $-1,576$ & 0,118 \\
PP $\left(\mathrm{X}_{2}\right)$ & 0,858 & 0,124 & 0,714 & 6,941 & 0,000 \\
Adjusted R Square & & & 0,367 & & \\
Sig. F & & 0,000 & & \\
\hline
\end{tabular}

Sumber: Data Penelitian, 2020

Dari hasil regresi linier berganda, maka dapat ditarik persamaan sebagai berikut :

$$
\mathrm{Y}=8,594-0,123 \mathrm{PA}+0,858 \mathrm{PP}
$$

Nilai konstanta $(\alpha)$ sebesar 8,594 mempunyai arti bahwa ketika variabel lain yaitu pemahaman akuntansi dan pemahaman perpajakan sama dengan nol, maka nilai kepatuhan wajib pajak naik sebesar 8,594 satuan. Nilai koefisien pemahaman akuntansi $\left(\beta_{1}\right)$ sebesar $(-0,123)$ mempunyai arti bahwa ketika pemahaman akuntansi naik sebesar 1 satuan dengan anggapan variabel lainnya konstan, maka kepatuhan wajib pajak turun sebesar 0,123 satuan. Nilai koefisien pemahaman perpajakan $\left(\beta_{2}\right)$ sebesar 0,858 mempunyai arti bahwa ketika pemahaman perpajakan naik sebesar 1 satuan dengan anggapan variabel lainnya konstan, maka kepatuhan wajib pajak naik sebesar 0,858 satuan.

Nilai Adjusted R Square adalah sebesar 0,367 yang mempunyai arti bahwa variabel independen pemahaman akuntansi dan pemahaman perpajakan mampu menjelaskan sebesar $36,7 \%$ variasi variabel dependen, sedangkan sisanya sebesar $63,3 \%$ dijelaskan oleh variabel lainnya yang ada diluar variabel yang ada. Nilai signifikansi $F$ adalah sebesar 0,000 yang nilainya lebih kecil daripada nilai $\alpha=0,05$ sehingga menunjukkan bahwa model regresi linier berganda fit dan layak digunakan sebagai alat analisis dalam penelitian ini.

Variabel pemahaman akuntansi $\left(X_{1}\right)$ memiliki nilai $t$ sebesar $-1,576$ dan nilai signifikansi sebesar 0,118 yang nilainya lebih besar dari 0,05. Hal ini mengindikasikan variabel pemahaman akuntansi $\left(X_{1}\right)$ tidak berpengaruh terhadap variabel kepatuhan wajib pajak sehingga hipotesis pertama $\left(\mathrm{H}_{1}\right)$ ditolak. Hal yang mungkin menyebabkan hasil pemahaman akuntansi tidak memiliki pengaruh terhadap kepatuhan wajib pajak adalah responden yang digunakan dalam penelitian ini adalah wajib pajak yang mempunyai hasil penjualan kurang dari 4,8 miliar per tahun dimana dalam aturan pajak wajib pajak tersebut dikenakan norma 0,5 persen dari penghasilan brutonya. Dengan demikian wajib pajak tidak memerlukan pemahaman akuntansi yang tinggi untuk dapat memenuhi kewajiban perpajakannya, wajib pajak cukup dapat menghitung secara mandiri dengan cara mengalikan norma 0,5 persen dengan omset per bulannya. Hal ini berbeda dengan wajib pajak yang mempunyai hasil penjualan lebih dari 4,8 miliar per tahun dimana wajib pajak tersebut diwajibkan melakukan pembukuan sehingga memerlukan proses akuntansi yang lebih rumit. Dengan demikian wajib pajak dituntut untuk memiliki pemahaman akuntansi yang baik. Hasil penelitian ini sejalan dengan penelitian yang dilakukan oleh Andi \& Putri (2020) yang menyatakan bahwa pemahaman akuntansi tidak memiliki pengaruh terhadap kepatuhan wajib pajak. 
Variabel pemahaman perpajakan $\left(\mathrm{X}_{2}\right)$ memiliki nilai t sebesar 6,941 dan nilai signifikansi sebesar 0,000 yang nilainya lebih kecil dari 0,05. Hal ini menunjukkan bahwa variabel pemahaman perpajakan $\left(\mathrm{X}_{2}\right)$ berpengaruh terhadap variabel kepatuhan wajib pajak sehingga hipotesis kedua $\left(\mathrm{H}_{2}\right)$ diterima. Semakin tinggi pemahaman perpajakan oleh wajib pajak maka kepatuhan perpajakan juga akan meningkat (Ananda et al., 2015). Hal ini terjadi karena banyak wajib pajak yang sudah mampu untuk melakukan dan melaporkan kewajiban pajaknya secara mandiri sehingga dapat ditarik kesimpulan pemahaman yang dimiliki oleh wajib pajak berkaitan tentang kewajiban perpajakannya cukuplah baik. Semakin tinggi tingkat pemahaman perpajakan maka pelaksanaan kewajiban perpajakan akan semakin baik sehingga dapat meningkatkan kepatuhan. Hal ini menurut Sumianto \& Kurniawan (2015) adalah sesuatu hal yang wajar karena seringkali wajib pajak tidak menjalankan kewajibannya bukan karena keinginan untuk tidak patuh, akan tetapi kerumitan perpajakan yang memaksa mereka untuk tidak patuh (perlawanan pajak pasif). Hasil penelitian ini sejalan dengan penelitian yang dilakukan oleh Kartika \& Aji (2015), Ananda et al. (2015), Suyanto \& Kholifah (2015), Sasmita (2015), Kartika \& Aji (2015), Oktafiyanto \& Wardani (2015), serta Rusli, Hardi, et al. (2015) yang mengatakan bahwa pemahaman perpajakan memiliki pengaruh positif terhadap kepatuhan wajib pajak.

\section{SIMPULAN}

Sumber utama dalam proses pembangunan, pembiayaan dan pemeliharaan yang dirasakan masyarakat saat ini merupakan salah satu bentuk manfaat yang dapat dirasakan melalui pembayaran pajak kepada negara. Kesadaran masyarakat untuk membayarkan pajak sesuai ketentuan yang berlaku merupakan hal yang diharapkan seluruh pihak khususnya negara. Target yang tidak dicapai beberapa daerah mengindikasikan bahwa masih banyak yang belum memiliki kesadaran untuk patuh membayarkan kewajiban perpajakannya. Oleh karena itu, kepatuhan wajib pajak merupakan hal yang harus ditegakkan dan penerimaan pajak harus dioptimalkan oleh negara khususnya wajib pajak itu sendiri.

Hasil penelitian ini menunjukkan bahwa pemahaman akuntansi tidak berpengaruh terhadap kepatuhan wajib pajak. Hal ini dikarenakan pemahaman wajib pajak sebatas melakukan pencatatan tanpa melakukan identifikasi atau pengelompokan transaksi berdasarkan akunnya. Pemahaman perpajakan dalam penelitian ini berpengaruh positif terhadap kepatuhan wajib pajak. Hal ini dikarenakan kemampuan wajib pajak untuk melaporkan secara mandiri sudah cukup tinggi, sehingga semakin tinggi pemahaman akan pajak semakin tinggi juga kepatuhan atas kewajiban pajaknya.

Penelitian ini memiliki beberapa keterbatasan. Pertama, dalam melakukan penelitian banyak responden yang susah untuk ditemui sehingga membutuhkan waktu yang lama. Kedua, penelitian ini hanya menggunakan variabel pemahaman akuntansi dan pemahaman perpajakan. Berdasarkan keterbatasan yang ada, penelitian selanjutnya diharapkan dapat memperluas objek penelitian untuk memperoleh hasil yang maksimal sehingga risiko adanya bias bisa diminimalkan. Penelitian selanjutnya juga menambahkan variabel- 
variabel yang lain seperti pelayanan fiskus yang sekiranya dapat mempengaruhi kepatuhan dalam melakukan kewajiban perpajakannya.

\section{REFERENSI}

Ananda, P. R. D., Kumadji, S., \& Husaini, A. (2015). Pengaruh Sosialisasi Perpajakan, Tarif Pajak, dan Pemahaman Perpajakan terhadap Kepatuhan Wajib Pajak (Studi pada UMKM yang Terdaftar sebagai Wajib Pajak di Kantor Pelayanan Pajak Pratama Batu). Perpajakan, Jurusan Administrasi Bisnis Fakultas Ilmu Administrasi, Universitas Brawijaya, 6(2), 1-9.

Andi, \& Putri, W. E. (2020). Pengaruh Pemahaman Akuntansi, Pemahaman Peraturan Perpajakan, Transparansi dan Akuntabilitas terhadap Kepatuhan Wajib Pajak Badan pada Kantor Pelayanan Pajak Pratama Tangerang Barat. IJAB : Indonesian Journal of Accounting and Business, 1(2), 100-120. https://doi.org/10.33019/accounting.v1i2.8

Dartini, G. A. A. S., \& Jati, I. K. (2016). Pemahaman Akuntansi, Transparansi, dan Akuntabilitas pada Kepatuhan Wajib Pajak Badan. E-Jurnal Akuntansi, 17(3), 2447-2473.

Djatmiko, H. (2018). The Effect of Taxpayer Understanding on MSMES Taxpayer Compliance. Russian Journal of Agricultural and Socio-Economic Sciences, 8(80), 216-220.

Fitri. (2020). KPP Pratama Madiun Tingkatkan Kepatuhan Pelaporan SPT Tahunan. Retrieved January 20, 2020 from https://radarmadiun.co.id/kpppratama-madiun-tingkatkan-kepatuhan-pelaporan-spt-tahunan/

Ghozali, I. (2016). Aplikasi Analisis Multivariete Dengan Program IBM SPSS 23 (Edisi 8). Cetakan ke VIII. In Penelitian. https://doi.org/10.1021/ol7029646

Ika. (2019). Ribuan Wajib Pajak Di Madiun Terancam Denda. Retrieved March 21, 2019 from https://gefmmadiun.com/2019/03/21/ribuan-wajib-pajak-dimadiun-terancam-denda/

Ikatan Akuntan Indonesia. (2013). Standar Akuntansi Keuangan Entitas Tanpa Akuntabilitas Publik. Jakarta: Dewan Standar Akuntansi Keuangan.

Kamil, N. I. (2015). The Effect of Taxpayer Awareness , Knowledge , Tax Penalties and Tax Authorities Services on the Tax Complience. Research Journal of Finance and AccountingOnline), 6(2), 104-111.

Kartika, Y. T., \& Aji, A. W. (2015). Analisis Pengaruh Pemahaman Ketentuan dan Presepsi Wajib Pajak tentang Peraturan Pemerintah Nomer 46 Tahun 2013 Terhadap Kepatuhan dalam Melaksanakan Ketentuan pada Wajib Pajak Pelaku Usaha Mikro Kecil dan Menengah di Kota Yogyakarta. Jurnal Akuntansi, 3(2), 56-62. https:// doi.org/10.24964/ja.v3i2.51

Kurniawan, D. (2020). The Influence of Tax Education During Higher Education on Tax Knowledge and Its Effect on Personal Tax Compliance. Journal of Indonesian Economy and Business, 35(1), 57-72.

Newman, W., Mwandambira, N., Charity, M., \& Ongayi, W. (2018). Literature review on the impact of tax knowledge on tax compliance among small medium enterprises in a developing country. Journal of Legal, Ethical and Regulatory Issues, 22(4).

Oktafiyanto, I., \& Wardani, D. K. (2015). Pengaruh Pemahaman Wajib Pajak, Kesadaran Wajib Pajak, dan Pelayanan Fiskus terhadap Kepatuhan Wajib 
Pajak Bumi dan Bangunan. Jurnal Akuntansi, 3(1), 41-52.

Oktaviani, A. A., Juang, F. T., \& Kusumaningtyas, D. A. (2017). The Effect of Knowledge and Understanding Taxation, Quality of Tax Services, and Tax Awareness on Personal Tax Compliance. Indonesian Management and Accounting Research, 16(02), 34-45.

Oladipupo, A. O., \& Obazee, U. (2016). Tax Knowledge, Penalties and Tax Compliance in Small and Medium Scale Enterprises in Nigeria. IBusiness, 8(1). https:/ / doi.org/10.4236/ib.2016.81001

Palil, M. R., \& Mustapha, A. F. (2011). Factors affecting tax compliance behaviour in self assessment system. African Journal of Business Management, 5(33), 12864-12872.

Panjaitan, H., Tarmizi, H. B., Daulay, M., \& Ginting, R. (2019). Effect of Good Governance, Tax Understanding, and Tax Sanctions on Taxpayers Compliance, Micro, Small and Medium Enterprises In Medan. Advances in Economics, Business and Management Research, 100, 663-669. https://doi.org/10.2991/icoi-19.2019.116

Pratama, A. (2018). Individual Taxpayer Characteristics and Taxpayer Knowledge: Exploratory Survey on Individual Taxpayers in Bandung City, Indonesia. Review of Integrative Business and Economics Research, 7(1), 338-349.

Putri, R. (2020). Tak Capai Target, Kepatuhan Pajak Dinilai Rendah. Retrieved March 1, 2020 from https://www.kabar-banten.com/tak-capaitarget-kepatuhan-pajak-dinilai-rendah/

Rizal Palil, M., \& Rusyidin Md Akir, M. (2013). The Perception of Tax Payers on Tax Knowledge and Tax Education with Level of Tax Compliance: A Study the Influences of Religiosity. ASEAN Journal of Economics, Management and Accounting, 1(1), 118-129. https:/ / doi.org/10.1016/S0022-3093(98)00430-X

Rohmawati, A. N., \& Rasmini, N. K. (2012). Pengaruh Kesadaran, Penyuluhan, Pelayanan, dan Sanksi Perpajakan pada Kepatuhan Wajib Pajak orang Pribadi. E-Jurnal Akuntansi, 1(2), 2302-2318.

Rusli, R., Hardi, H., \& Pakpahan, Y. E. (2015). Pengaruh Pemahaman Akuntansi, Pemahaman Ketentuan Perpajakan dan Transparansi dalam Pajak terhadap Kepatuhan Wajib Pajak Badan. Jom. Fekom, 2(1), 1-15.

Rusli, R., Zirman, Z., \& Puspitasari, L. (2015). Pengaruh Kesadaran Wajib Pajak, Tingkat Pemahaman Wajib Pajak, Pelayanan Fiskus dan Sanksi Pajak terhadap Kepatuhan Wajib Pajak (Studi Empiris pada Pengusaha UMKM di Kpp Pratama Senapelan). Jom. Fekom, 2(2), 1-15.

Saad, N. (2014). Tax Knowledge, Tax Complexity and Tax Compliance: Taxpayers' View. Procedia - Social and Behavioral Sciences, 1069-1075. https://doi.org/10.1016/j.sbspro.2013.12.590

Sasmita, S. N. A. (2015). Pengaruh Pemahaman Wajib Pajak, Pelayanan Fiskus, Kesadaran Wajib Pajak dan Sanksi Perpajakan terhadap Kepatuhan Wajib Pajak Pemilik Usaha Kecil Menengah dalam Pelaporan Kewajiban Perpajakan di Semarang (Studi UMKM Di Kota Semarang). Journal of Accounting, 1(1), 1-17.

Setyorini, C. T. (2018). Analysis of Implementation of SMEs Tax Enforcement: The effects of tax justice dimensions, understanding of tax ac-counting on SME's tax compliance. Journal of Economics, Business \& Accountancy Ventura, 
21(1), 1-12. https:// doi.org/10.14414/jebav.v21i1.845

Sumianto, S., \& Kurniawan, C. H. (2015). Pengaruh Pemahaman Akuntansi dan Ketentuan Perpajakan Serta Transparansi dalam Pajak terhadap Kepatuhan Wajib Pajak Orang Pribadi Usahawan Pada UKM di Yogyakarta. Journals Modus, 27(1), 41-51. https:/ / doi.org/10.24002/modus.v27i1.567

Suwiknyo, E. (2019). Hingga Juli 2019, Kepatuhan Wajib Pajak Baru 67,2 Persen. Retrieved August 7, 2019 from https://ekonomi.bisnis.com/read/20190807/259/1133668/hingga-juli2019-kepatuhan-wajib-pajak-baru-672-persen

Suyanto, S., \& Kholifah, D. A. (2015). Pengaruh Pemahaman, Kualitas Pelayanan, dan Sanksi Perpajakan terhadap Kepatuhan WP Pelaku UMKM Sesudah Penerapan PP NO.46 Tahun 2013 (Survey Kantor Pelayanan Pajak Pratama Wonosari). Jurnal Akuntansi, 3(2), 16-27. https://doi.org/10.24964/ja.v3i2.48 Umar, H. (2008). Metode penelitian untuk skripsi dan tesis bisnis. Jakarta: PT. Rajagrafindo Persada. 